\title{
装具をめぐっで
}

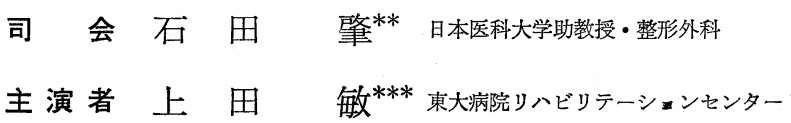

\section{司会（石田 筆）}

今回砂原学会長の発案によりるして,リハビリテーシ ョン医学でも特殊な位置を占める装具阔し, 東大中央 診療部リハビリテーションセンターの上田敏先生を主演 者として、ご講演をいただくと同時に問題を提起してい ただき，論じていきたいと思います。和手許てある抄録 の順従って，進行いたします。な和時間の都合で今回 は下肢の装具のみ飞限って扔話を願います。

上田先生ぞうぞ。

\section{主演者（上田 敏）}

ただ今ご紹介いただきました上田でございます。主演 者として，その任湛えるものではございませんが，問 題の緒を作る意味で，扮話を進めさせていただきま g。

今日ほ, 石田先生から和話がありましたようと, 下肢 の装具(Brace) を中心として扮話いたします。装具は, 従来整形外科領域に淞いて開発され, 現在リハビリテー ションの重要な手段として活用されているのは, ご存知 のと和りであります。しかしながら，医学教育活いて， 補装具関しどの程度教育されてきたかとい光ば，それ はきわめて微々たるものであり，更飞その処方，出来あ がり時の検查 (check-out), 使用法の指導などそ関して, その最終責任者である医師の知識と経験は不十分であ り，ともすれば，装具製作者に任せきりというのが現状 でありました。私自身自分で装具を処方し少しく経験を 重初てまいりまして，はじめていくつかの細かい点が意 外飞重要であることに気づいてまいりました。

\footnotetext{
* Braces

** ISHIDA, Hajime

*** UEDA, Satoshi
}

これはあたかも外科医が手術をする場合に，適応を決 め, 法則従って施行するのと同じ注意が，装具製作に 当っても重要であると感じたわけであります。特泣具 の一つ一つの部分と, その全体との関係ということがや はり医師の責任として重要かと思います。

まず扔手許に差しあげましたプリント（略）飞「装具 製作にあたっての医師の仕事」そついて書いて特きなし た。常識的ですが，(1)処方 (2)製作指導 (3)仮合せ (4) 出来あがり時の検査（チェックアウト）の順で, 特にチ ェックアウトが重要で，これをないがしろにしますとう まくいきません。それから (5)訓練の指導 (6)使用法掠 よび保守(maintenance) の指導が重要です。(5), (6)は, 医師のみならず，理学療法士も当然行なわねらない ことであります。私自身をらりかってみまして，(1)か ら(4)末では，比較的一生㲘命やって掠りますが，(5)，(6) そ関しては,ないがしろにしがちであり, 肝心の患者に 対しての使い方の指導を忘れがちとなります。すなわち せっかく良い装具を作り委てても，たと光ば足内反，外 反を矯正する T-strap の結び方を正しく指導しなかっ たため効果を奏しないなどもその 1 例であります。この 場合(1)から(6)までを円滑飞行なうと際し，医師として， 基礎知識として装具の各部の名称と機能をよく理解する ことが重要であります。同時にとの底にあります生体力 学 (Bio-mechanics) 的な考察も重要であり末す。それと もう一つ，われわれの置かれている特殊な位置でありま すが，元来装具が西欧的な生活様式飞適応して発達した という事実で, これをこのまま日本式生活に応用する場 合, いろいろの改変 (modification) を, しなければな らないことであります。この点は，私自身も経験が不十 分なので, 後で諸先生との討論の中で, ご教示願いたい と存じます。 
表 1 下肢装具 (Brace) の各部の名称

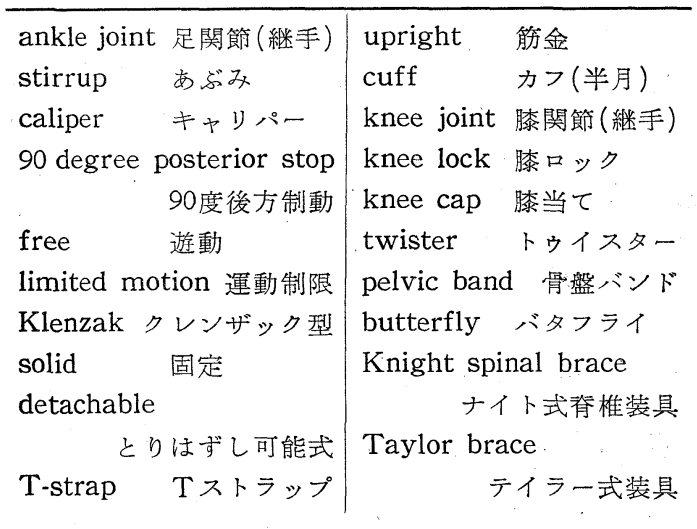

以上で前置きを終り, 具体的な話しに入りたいと思い ます。

\section{I. 下肢装具の各部の名称}

下肢装具の各部の名称でありますが, 現在学会で決め られた正式の訳語がありませんので，一応この表のよう なととばを使うことにいたしました(表1)。かかること ばで実際慣用されていることが多いのですが，訳語とし ては，検討の余地があると思います。

\section{II. 足関節の生体力学的考察}

次江足関節の生体力学的考察に入ります。

足関節の生体力学について, あまり詳しく追求いたし ますと，いろいろの問題が残されて扮り，私自身とこま で詳しく存じませんので, 装具と関する最低限のことに つき招話しいたします。

\section{1. 足関節固定の静力学}

図 1 は足関節飞尖足のある時江固定する方法の考察で す。その尖足も，弛緩性麻盘によるものではなく，中等 度以上の痙性麻痺のある場合とします。これを固定する 場合, 他の関節固定と同様飞, 三点支持 (three point support）の原理が適用されます。この場合，どこにそ の三点があると考光るかが重要であります。足関節固定 に関して3点がどこにあるかと考光すすと, 図 1 (a)の 矢印で示した 3 カ所がそれ机あたります。この場合, 中 心のもの, すなわち, 前上方から後下方へ, 踵の方向飞 向うものがもっとも重要なものです。もしこれが弱けれ ば, 俗にいう「踵が浮く」という現象が（靴の中で）起 こり, 図1（b）のよう飞足関節底屈が起こってしまいま す。こう考完ますと, 結局足関節固定《は靴の作り方の 上でこの部の固定をいかに確実にやるかが根本的に重要 だということになります。特に女性の蜼ねつま先が浅い ので, しばしば, この部に補助バンドを加える必要が起
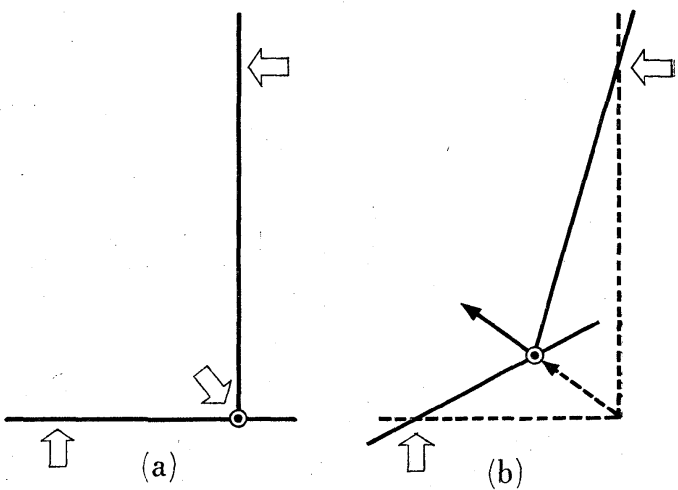

図 1 足関節固定の静力学

こってきます。また，足底板式（またはサンダル型）の 場合にもこの部の固定をしっかりやれば，爪先のほうを 締める必要はあまりないことになります。

次に固定の力関係を考える必要があります。足底と下 腿半月にかかる力は招たがい氏釣合っているわけですが はき心地が良いためには，側方支柱の長さ，半月板の位 置, 靴の大きさなどの釣合いのとれたものが良いわけで あります。また足底板が中足指関節を越えると, 立脚期 の後半 (特に toe-off の時) にいろいろの障害が起こっ てまいりますので避けなければなりません。

以上が，固定の静力学的な考察であります。

\section{2. 足関節の動力学}

次に, 歩行に際しての, すなわち足関節の動力学に入 りたいと思います。ここでは，各種の足関節（接手）が 歩行に対しいかなる影響を文ぼすかについて, 論じたい と存じます。

（1）あぶみ式とキャリパー式 まずあぶみ式 (stirrup type) とキャリパー式 (caliper type) の優劣につ いてですが, 前者は, 生理的な足関節の位置にできるだ け近いところにあるのを特色とし, 後者は靴の底に軸の くるものであります。いずれも $90^{\circ}$ 後方制動とか, 制限 つきにすることが可能であります。なぜか良くわかりま せんが，英国ではこのキャリパー式が良く用いられてお ります。

理論的には, 生理的, あるいは解剖学的足関節軸と, 装具の足接手の軸とは，できるだけ接近していたほうが 良いのは当然であります。この軸のずれは，半月(cuff) のところに影響し, 半月が下腿にくいこんだり, 離れた り下腿を摩擦したりすることは常識で考えられるところ であります。caliper の利点としては，足底での取りは ずしができることがありますが，もちろんあぶみ式で も，取りはずしができます。力学的には，あぶみ式が適 していると考完す。 

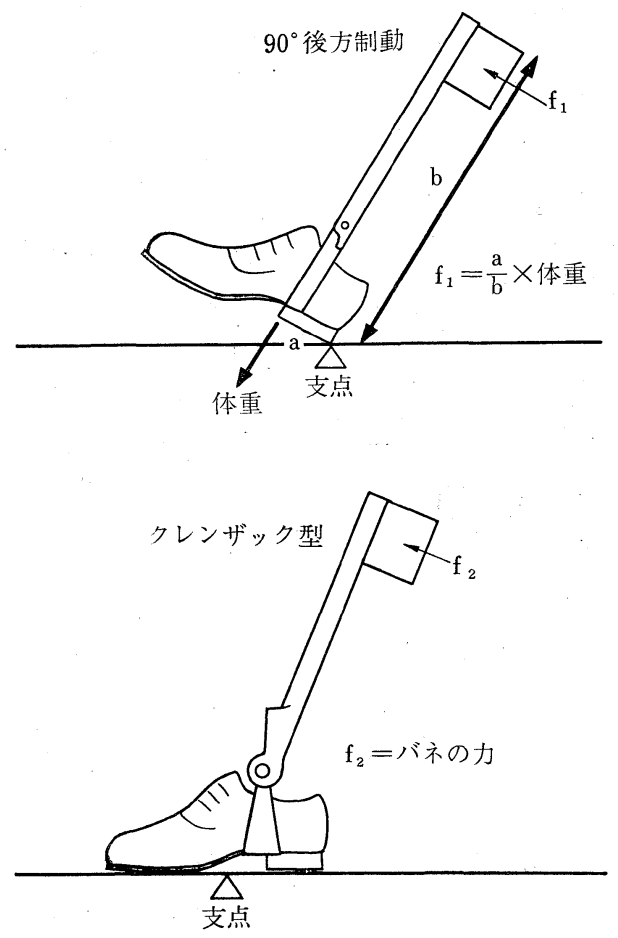

図 2 足関節の動力学 (Heel contact 時)

（2）90度後方制動とクレンザック型 クレンザック 型々, ご存知のごとく, バネが入って和り, 足の背屈を 助けますが，そればかりでなく，同時にある程度の底屈

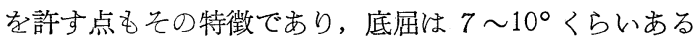
いはそれ以上のこともあり，背屈は $20^{\circ}$ あるいはそれ以 上です。踵接地 (heel contact) の時, 通常の90度後方 制動では底屈が不可能ですが，Klenzakの時飞ば正常歩 行飞近く，底屈を許します (図2)。

したがって90度後方制動の時, 実際にはいてみますと すぐわかりますが，踵接地の時回転モーメントが働いて 半月が腓腹部を前方に押して，膝折れをきたし非常に不 愉快なものであります。この場合の力 $\left(\mathrm{f}_{1}\right)$ はほぼ $10 \mathrm{~kg}$ くらいと推定されます。この点 Klenzak は有利で, バ ネの力のみが腓腹部を押し，この力 $\left(\mathrm{f}_{2}\right)$ は，測定しま すと $1.5 \mathrm{~kg}$ くらいで $\mathrm{f}_{1}$ の 7 分の 1 くらいの力となりま す。それゆ交 90 度後方制動は, 必然的飞不自然なるので あるといえます。ただしこれは heel contact の時期に ついてのみの議論であります。一般に Klenzak は, 現 在 polio のごとき弛緩性麻疸によるものに向くと考えら れて括りますが, 私は㽷性麻痺のごく軽いものには, 使 っても良いと思います。

石田先生や私が教えを受けましたニューヨーク大学の 学派では，こ机を痤性麻疩に用いることに強い反対を示 して和ります。というのは, 痓性麻痺は, 伸展反射の䒕

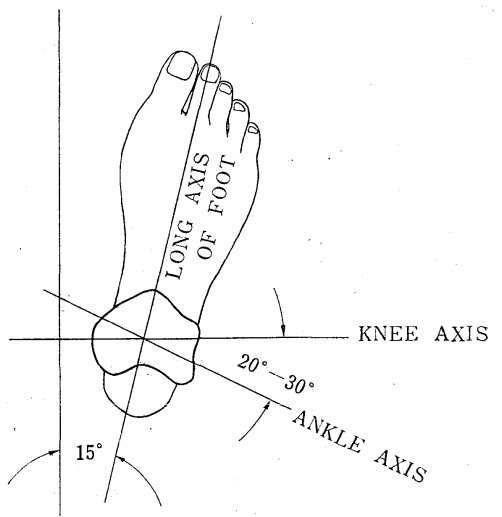

図 3 足関節軸の定め方 (Lehneis, 1964)

進している状態でありますので，Klenzak では，この 反射をたえず刺激していることとなるというわけです。 ところがアメリカでも西海岸のほうでは, 平気でこれを 痤性麻痺に用いて和ります。

私は踵接地の時の不快（㯟折れ）はできればないほう がよいので，その意味で，軽い病性麻瘏には90度後方制 動より Klenzak がよいと考皇るおげす。現実にも使 ってみて具合がよいようです。ただし, 痤性（より正確 には伸展共同運動）の強い例ではスプリングが抗しきれ ずに，底屈が起こってしまうのでよくありません。

義足の SACH foot (Solid Ankle Cushion Hẹl) ご存知のようと足関節はなく踵部のクッションで, 底屈 と同様の効果が得られるのですが，90度後方制動であ。 ても，踵の部分が非常飞柔くできていれば, SACH foot と同じ理屈で膝折れを軽減できるのであります。ただ し，日本では，ゴムの良い材質を得るのが困難であり maintenance 飞も問題があります。

次に T-strap (または Y-strap) これはご承知のよう に内反 (外側 T-strap) 特よび外反（内側 T-strap)を 防ぐものであり，この場合も，三点支持の原理が考光ら れます。主な支持部である足踝部のところには，かなり の力が加わりますので, pad るあてて保護することが重 要となります。

(3) 足関節軸の設定 次にこの問題に移りますが, これは非常にむずかしい，いろいろの議論のあるところ であります。従来の足関節軸のもとめ方は，ほぼ内踝の 下縁と，外踝の中央を通る軸，乙かもこれが水平でなけ ればならないというのでありました。上方から見た場 合, 下腿長軸と, 足関節軸との関係についてはいろいる の議論があります。Orthopedic Appliance Atlas に出 ている図では，足の長軸は進行方向に対し 10〜15०の toe-outをつけなければならない，乙かも足関節軸は進 行方向飞垂直（膝の軸と一致）飞つけねばならないとし 


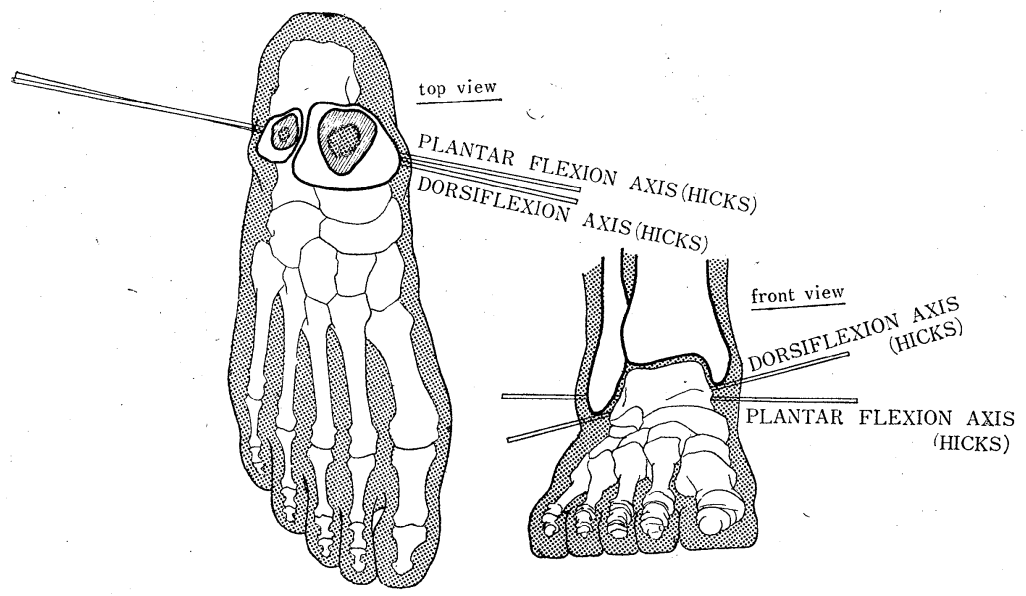

図 4 足関節軸 (1) (Desai, Henderson, 1961)

て和ります。しかもこれは，長下肢装具，短下肢装具の どちらてついても同様であるといわれています。一方， ニューヨーク大学の Lehneis は, orthotist ですが, 次 のようといっています。すなわち解剖学的な足関節軸は 足の長軸に垂直な線から 5 から $15^{\circ}$ くらいずれているも のであり, toe-out が $15^{\circ}$ あるとすると, 膝関節軸に対 し $20^{\circ}$ から $30^{\circ}$ の角度ができることになります。これは 先注どの線（滕の軸と一致）とは全く逆のむきとなりま す(図3)。これとはアメリカでもいろいろの人が迷い 疑問を持たれています。一方，バークレイとサンフラ ンシスコのカリフォルニア大学の Biomechanics laboratory の人達が，特飞 Dr. Inmann 等が中心飞実際の 人間の体とついて足関節の位置を計測測定する装置を考 えた実測值とよりますと，いわゆる足関節（talocrural joint) 飞ついて水平位から底屈する時の軸と背屈をする 時の軸とは既に異なっていることがわかってきて括りま す。底屈時の軸は水平飞近いが，背屈時の軸は，むしろ 内踝と外踝とを結ぶ斜めの軸であります。これを上から 見ると，この二軸は多少ずれているが，ほぼ同じ軸とな ります（図 4)。次江距骨下関節 (subtalar joint) が, 大きな問題となりますが，ほぼ足の後下外方から前内上 方飞向う斜めの線で，これが実際の歩行に際し，大きな 運動をしていすす（図５）。その他足部のいくつかの小関 節がすべて歩行に際し運動しているのでありますが，先 ほどの 2 らが基本的なものであります。

したがって, 彼らは, カリフォルニア大学式の 2 つの 軸を持った Brace を試作し，これを履いていると， Brace をつけて歩いているのを感じないほどであるとい っています (U.C.S.F.-B 式 2 関節短下肢装具)。これは 結局ただ一つの軸では足関節の動きを正確に模做するこ とは不可能だというに等しいわけです。ですからあく

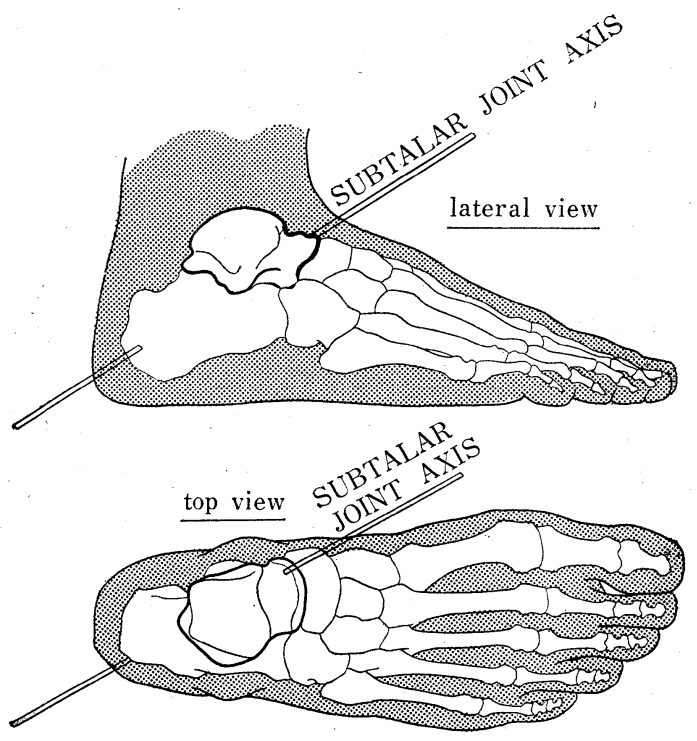

図 5 足関節軸 (2) 距骨下関節 (Desai, Henderson, 1961)

まで一つの軸でいくとすれば何かの妥協をしなければな らなくなるわけです。私はとれで進行方向值角という 線をとることにして扬ります。これであまり支障を来し ていないのですがこれはあくまで妥協でありますから， 諸先生よりご教示をいただきたいと思いすす。

\section{3. 堎関節部の考察}

次に滕関節につき述べますと，これは足関節に比し力 学的には簡単であり末す。

（1）膝関節の固定 すなわち膝折れを予防するため 三点支持の原理が適用されますが，関節中心から半月ま での距離が長ければ長いほど，固定力は良いわけであり ます(図6 a)。 


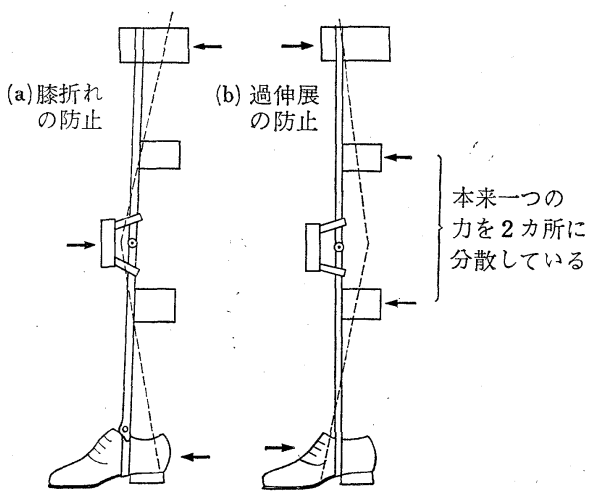

a 膝折れの防止 $\mathrm{b}$ 過伸展の防止

図 6 膝関節の固定（三点支持）

次滕反張 (genu recurvatum) の予防ということで すが，この時は問題がちょうど逆になり，関節軸に近い ほうの2つの半月（cuff）の位置が近ければ近いほど効 率が良くなるわ汗です。しかしながらいくらでも近づけ られるわけではなく, 㯟屈曲時に滕窩部に半月がくいこ ・まないところまでが原則です（図6 b )。次に滕あて (knee cap) ですが，従来の日本の装具にはこれがない のが多いのですがそれは全く三点支持の原理に反するこ とであり，力を無䭾にしていると考えられます。

（2）膝関節の位置の設定 Orthopedic Appliance Atlas にも図が出ていますが，結局足関節の場合と同様 にどこかで妥協が必要で, 軸の位置恃, 正常の関節の軸 に近く, 側面では前後径のほぼ中央にもって来るように して和ります。

ただあらゆる角度で, 正常軸に近づけることは困難な ので, 結局伸展位と, $90^{\circ}$ 屈曲位の 2 つの場合飞正常の 軸に近ら゙くように工夫しています。その他膝に関しては 安定型遊動滕関節 (off-set) や， 伸展補助装置の問題が ありますがここでは省略いたします。

\section{4. 股関節部および躯幹の考察}

（1）股関節の位置とアライメント これがまず大き な問題となります。標準として, 股関節の位置は, ほぼ 大転子の位置にあり，進行方向に平行することが原則で あり，また骨盤帯 (pelvic belt) の位置は, 腸骨前上欶 より下の部分で最も固定されやすいといわれています。 しかて三点支持の観点からすると，これだけで柱不十分 であり，骨盤ベルトを多少後方で下げること拉よび，時 に butterfly をつけることが必要となります(図7)。

\section{《司会》}

それでは，区切りがよろしいので，この辺で一応ディ スカッションに入りたいと存じます。上田先生より足関

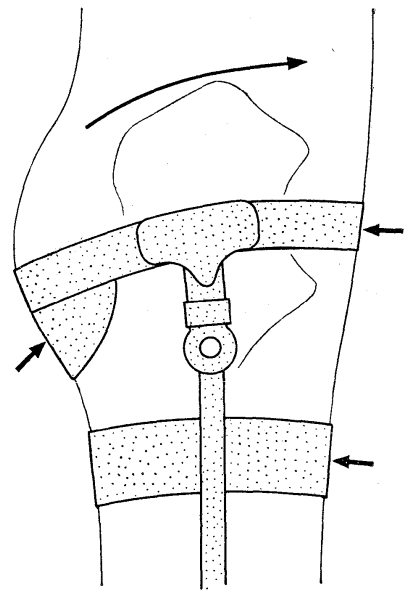

図 7 股関節固定の力学

節軸の設定の困離さ，それに Lehneis, U.C.S.F.-B 型な どの供覧がありましたが，足関節についての皆様のご意 見をうかがいたいと存じます。

\section{《質問》 明石 謙 (岡山大学整形外科)}

演者の和話しに詨し，何も追加するところもありませ んが，2，3質問いたしたいと存じます。

（1）足関節の dorsiflexion と plantar flexionの軸をど のように決めているか,すなわら軸を決める場合に rotationのことについては触れられましたが, 水平面に挌け る軸についてはどのように決めて抽らるでしようか。

（2）足接手の位置が, 前方または後方にずれた場合，ど えな変形が起こるか, 以上 2 点につき,質問いたします。

\section{《答え》上田 敏}

第 1 の質問に対して, 私の考えでは水平ということと 進行方向に対して直角にすることにしています。前後 は問題があり, 内踝下端と外踝の中央を通るようにし malleolus からのずれを大体同じになるように妥協的な 方法をとっています。これではまずいことがありました ら教えていただきたいと思います。

第 2 質問に対しては, 私は経験がありませんので拉 教光下さい。

\section{《追加》 明石 謙}

これは，N.Y.U. で教わったことですが，前方とずれ ている時は内反, 後方にずれている時は外反の変形が起 こるといわれています。外反の経験はありませんが，内 反の経験は 2,3 ありすす。

\section{《司会》}

足の軸の設定に関し, 飯田先生, 何かご教示いただけ ませんでしょうか。 
《答え》 飯田卯之吉（国立身体障害センター）

私どもは，製作上の点から決定いたして抲りますが， 高さは lateral malleolus が中心となり, 膝接手軸に足 関節軸が平行になるよう飞決めて和ります。すなわち， 膝接手軸, 足接手軸が進行方向に直角になるようとして 抢ります。Lehneis のいうことるわかるのですが，そう すると両方の upright（側方支柱）が parallel といかな いのですね。すなわちどちらかがずれ，内側が前にずれ ます。それでごまかしかもしれませんが parallel 沈なる ようとして招ります。

\section{《司会》}

下河辺先生ご意見は。

\section{《答え》下河辺征平 (国立療盖所東京病院)}

足接手飞ついては, 私は $\mathrm{SACH}$ foot 的な足部が良 いのではないかと考光て叔ります。その理由として，た とえば，足関節全固定術 (panarthrodesis) では，その 下肢の TKA 線さえ, 正しいアライメントを保って执れ ば，良い効果を得ることができるのであり，乙たがって まず整形外科的観血的に固定の行ないうるものは，こ れを先行し，その余地のないものとは， SACH foot 的 のものが良いと思います。

またスライド(略)のごとく足部のない長下肢装具も， 足関節固定例征処方できます。これでずり落ちないだ ろうかという心配がありますが，との解決策として，半 鋼の筋金（側方支柱）を使用し，㯟直上の内外の適合， 足直上の（すなわち内外踝つ彎曲飞合せて）適合飞注意 すれば防止できると思います。日本では，足関節固定術 をもっと積極的に行なうべきであると思います。

\section{《司会》}

ただ今, 下河辺先生の貴重なご経験より, 私ども大い 飞披掖されるところが多かったのでありますが，その他 ご意見はございませんか。

\section{《発言》松本義康 (九州学災病院)}

われわれも九州労災病院で足関節の生理軸に関しては 進行方向飞直角飞する方向, また Lehneis のいうょう な20〜30外方向ける方法をやってみなしたが, 結局 特記するような大差はないようと思って和ります。その 点 Caliper 飞招いても同様と思います。また患者側から しますと，靴を履きたがらない者が多く，特に脊損患者 では, 靴のない「足づり」が路面に応じた歩き方ができ るので, 最も好まれているようで, 装具はなるべく少な く, 簡単なものが良いと考光られます。

\section{《演者》}

私も松本先生と同意見で, maintenance の問題より, できるだけ簡単なものがよろしいと思います。足部につ きまして, 東京という環境のせいか, 片麻痺の患者で,
靴も好えで用いられます。また田舎の初婆さんのごとく 一生に一度も靴をはいたととのないものにはサンダル型 のものを処方して好成績を和さめて和ります。しかし室 内と戸外では足関節の角度が変わってしまうので, 詳し くはむずかしい問題があると思います。次にパラプレジ アの問題では, 私は服部先生のいらした頃に九州労災に まいり，実際と足部のない Brace を喜しで使用している のをみて和り,その際足部の変形や, 関節炎が起こらな いかということ関して質問しましたところ，いまだか つて, 全然経験したことがないことを聞いて驚いた次第 です。

\section{《司会》}

それでは, 以上で足関節軸の問題を一応打ちきり, 疾 患ごとに特に注意すべき諸点につき，具体的な䄧話しを もう少し上田先生に進めていただきたいと存じます。

\section{《演者》}

\section{5. 下肢装具の処方例}

それでは, 片麻痺, 対麻瘦, ジストロフィーにつき, 具体例を示しますが，すべてプリントに書いてあると招 り（表2）であり，あるり問題はないものと思います。 時間の都合上, 要点と思われる点についてのみ述べたい と思います。

（1）片麻盘について 先に Klenzak そつき述べ したが, ごく軽度のものは，ゴムバンドによるアンクル サスペンジョンで十分ですが, 内反, 外反のあるもので は、これでは不十分です。その時にはいわゆる Klenzak 型のものが痓性の弱、尖足には有効と考光られるす。㾏 性の中等度以上のものでは, $90^{\circ}$ 後方制動つき短下肢装 具が良いのですが, 膝折れの問題が，いつもつきまとう のであります。実際と補装具飞より歩容が良くなっても 患者は歩きとくいことを訴光ることがあり，軽い㾏性の ものでは $90^{\circ}$ 後方制動は考光ものであります。内反足, 内反尖足飞は, 外側 T-strap を用います。もし, 内反 足のみの時には, 足関節を遊動 (free) 飞するとともで きすす。外反足は多くないのですが，足関節の lateral stability が悪くなった (frail joint) ためと体重をかけ る立脚期に見られることがあり, 内側 T-strap が処方 され方。長下肢装具については，先ほど述べた固定以 外飞問題はありません。䐐装具は私は下河边先生の招考 えと異なり，一時的のものと考光ております。反張膝で は先に述べた通り cuff をできるだけ膝関節に近づけま す。ただし $90^{\circ}$ の後方制動だけでも防げることがありま

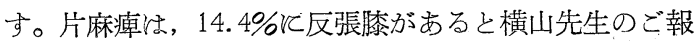

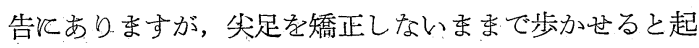

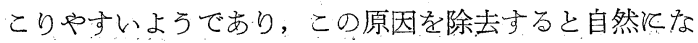


表 2 下肢装具の処方例

\section{A. 片麻㿁}

(1) 尖足（垂れ足，疰性のないまたはきわめて弱いも

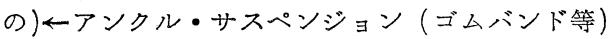

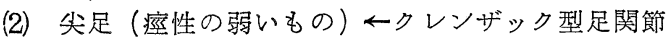
つき短下肢装具

（3）尖足（痙性中等度以上） $\leftarrow 90$ 度後方制動足関節つ き短下肢装具

（4）内反足または内反尖足な外側 $\mathrm{T}$ ストラップつき短 下肢装具（足関節は遊 動, クレンザック，また は90度後方制動)

（5）外反足（立脚期） ↔内側 Tストラップつき短下肢 装具

（6）膝折れ（大腿四頭笳の筋力低下） 世膝装具（多く は一時的）または長下肢装具（膝ロックつき）

（7） 反張滕（膝関節過伸展） $\leftarrow$ (a) 90 度後方制動足関 節つき短下肢装具 (尖足 が原因で, 過伸展が軽度 の場合

$\leftarrow(\mathrm{b})$ 長下肢装具（滕関 節遊動一四頭筋または ハムストリングスの筋 力低下が原因の場合)

（8）ぶえ廻し歩行, 骨盤㑡方挙上, 股関節外旋位歩行 な短下肢装具で尖足を矯正しただけで直ることが ある。

B. 対麻瘦

（1）尖足または内反尖足な両側短下肢装具（90度後方 制動，その他）

(2) $\mathrm{L}_{4}$ 以上 $\mathrm{L}_{2}$ 以下の対麻痺 両側長下肢装具（膝関 節ロックつき)

(3) $L_{1}$ 以上の対麻㾇↔骨盤バンドを上記に加える

(4) $\mathrm{Th}_{10}$ " も長下肢装具のみでょいとの見解もある)

C. 筋ジストロフィー症

障害度 5 以上ヶ両側, 膝伸展補助バネつき長下肢装 具（膝関節運動制限, 足関節90度後 方制動または運動制限）

拈るとともあります。その他, 異常歩行のすべてが装具 で治るわけではありませんが，尖足に由来するものね， これを矯正することてより矯正することができる場合が 多いようです。

（2）対麻㾇について これは，全く議論の分かれる ところであり, 一応私どもが教科書的に, ニニーヨーク 大学式济わったところでは, 長下肢装具の適応は, 大腿 四頭筋の弱いものに用いられることと異論はありません が，骨盤バンドをつけるかつけないかは， $\mathrm{L}_{1}$ のレベル 以上だと一応つけることにして和ります。 $\mathrm{Th}_{10}$ 以上で は, ナイト式脊椎装具をつけることてして和ります。乙 かしながら股関節は過伸展により安定性を得ることがで きるので，かなり高いレベルのものでも骨盤ベルトなし
表 3 下肢装具チェック・アウトの要点

A.はかせる前にしらべること

(1) 靴の形, 締め方, 靴底の弾力性, 靴底の接地（底 金の突出の有無)

（2）足関節の可動範囲（靴底を標準に！） $\rightarrow$ レンザ ック型のバネの強さ

(3) 足関節 (内外 2 コ) の軸の一致

動きの滑らかさ

カノイズの有無

（4）足関節（とりはずし可能式）のとりはずしの難易

(5) 膝関節の内外 2 軸の一致 $\rightarrow$ 動きの滑らかさ

（6）滕（股）関節ロックのかけはずしの難易

(7) 革部の仕上げ

B．はかせてしらべること（坐位）

（1）靴が足に合うかぞうか，着脱，締め方の難易 (足の指は曲っていないか?)

(2) Tストラップの位置（中心が顆部の中心と一致す るか?）および効果

（4）笳金と下腿（大腿）との距離

（5）膝関節の位置（股・膝屈曲位で大腿, 下腿のカフ の位置をみる)

（6）膝当ての形態, 締め方の難易

（7）大腿, 下腿カフ (半月) の位置（高さ）と形状 (幅, 深さ)

(8) 股関節の位置 ((5)之同時)

(9) 骨盤バンド，バタフライの適合（骨部への压迫を 避けているか? 殿筋への圧迫は均一であるか?)

(10) 体幹部の適合

(11) 患者の快・不快

C. 立位と歩行時に調べること

(1) 立位時のアラインメント

(2) 立位時の鞉底の接地

(3) Tストラップの効果（立脚期と振出し期の比較）

（4）歩行異常の有無 ホイップ (外側, 内側)

踵接地時の股関節外旋

(5) 関節のノイズの有無

（6）患者の快・不快

でも使用でき，いわんやナイト式装具は不用であるとい う考宇もあり, これらについては, 経験のある先生に和

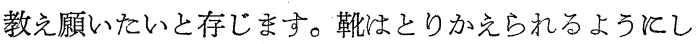
て, 日本式生活飞適応できるようにし，あるいはカバー をつけて室内でも用いられるようにして和ります。

一つ扮教兄願いたいのは，股関節過伸展を長期間強制 する時, 股関節炎やloose joint 動摇関節などが来ないで あろろかという心配であります。骨盤バンドの効用は, 骨盤の固定のみでなく, 股関節の横のふれ, 回旋を防ぐ という意味もあると考完られます。

（3）筋ジストロフィーについて 本日, 徳島大の遠 藤先生のご報告 (一般演題 24 . 筋ジストロフィー歩行用 装具「バネ付下肢装具」の理論と実際) がありました 
が，非常にユニークなご研究と思われます。ニューヨー ク大学では, 装具を用いませんが, クリーブランドの Vignos p Spencer らは昔から長下肢装具を用いて招 ります。私も徳島式を一部改良して追試してよい結果を 得て扮ります。

これで私の話を終りたいと思います。時間がなくて， プリントの最後にあるチェックアウト（完成時検査）飞 ついて述べる時間がなくなりました。チェックアウトは 医師の仕事としては処方についで重要なものであり，こ れを細心に行なうかどうかで装具の良さが決まるといっ て過言ではありません。今日は述べる時間がありません のでプリント（表3）を报読みいただけれげ幸いです。

\section{《司会》}

それでは，徳島の遠藤先生に筋ジストロフィー飞対す る下肢装具の要点に関し，扣話し願いたいと存じます。

\section{《発言》 遠藤寿男 (德島大学整形外科)}

私どもの開発しました滕伸展補助バネつき装具の要点 は, 次の 2 点にあります。すなわち

(1)立位の際の重心線が，足底を過ぎる位置は，踵部後 端より全足底長の約40\%のところを通過するようとする こと，抒よび，(2)立位時の身區幹の支持は大腿部の cuff で行ない, 重心線は cuff 後端の中央部を通るようにす ることであります。

\section{《司会》}

それでは, 先添ど問題になりました脊髄損傷のレベル と，Brace を用いるべき範囲とつき，皆さまのご意見を うかがいたく存じます。九州労災の松本先生いかがでし ょうか。

\section{《発言》 松木義康}

実は Knight spinal, pelvic band をつけるか否か、 ついては，こちらのほうが，招尋敞したいところです。 ただ私どもの経験では, pelvic band, Knight は注とん どいらないようと思います。したがって N.Y.U.のいう レベルよりずっと切り下げてもよいようと思いすす。

大部分の患者は， long leg brace を用い，代償性の lordosis で，松葉杖歩行を行なうものが压とんどであり ます。

\section{《司会》}

どうもありがとうございました。

それでは，下河辺先生いかがでしょうか。

\section{《発言》下河辺征平}

私は損傷されたレベルいかんとかかわらず，股関節過 伸展さえ可能ならば, 補装具の股接手は不要でないかと 思います。

Knight spinal の問題は, 結局腹筋力の状態次第で,
それが腹部臟器を安定させえない状態ならね゙，「腹帯」 が必要であると思います。

\section{《司会》}

どうもありがとうございました。他にどなたかご意見 ございませんか。

\section{《発言》明石 謙}

N. Y.U. 式の考光方ですが, $T_{10}$ 以上の脊髄損傷患者 飞脊椎用装具を付加する理由の一つとして，心理学的な 問題として, 初期には over-bracing を行ない, 不必要 になれば切り下げ，患者に心理的に良い影響を与える点 と, 受傷後 6 力月は脊椎装具を用いたほうが良いという 2 つの点がその理由と思います。

\section{《司会》}

どうもありがとうございました。

結局, N.Y.U. 方式と従いますと損傷の高さと補装具 の適用範囲は, 経験より得られた rule of thumb とい うことになって招りますが，皆さまの和話しを総合しま すと, 初期炕は, 安静と心理学的な意味で, $T_{10}$ 以上の 傷害では, Knight 脊髄装具をつけることる正当化され るが，日本の諸先生の経験では，大部分の症例が股関節 の過伸展, 腰椎前彎増強により Jack knife を防ぎ, 松 葉杖歩行が可能であることが了解されをした。補装具は もちろん, 本人の疾患の種類, 程度, 範囲, あるいは生活 様式, それと年龄, 性別なぞあらゆる要因を考慮して, 処方されるべきで, 補装具の individualization という こと，その患者さんに最も適したものを作るということ が重要かと存じます。

最後に, 全体のまとめとして, 本日のセミナーをふり かえってみすすと，上田先生の長時間の広範囲にわたる 貴重な拎話しは, まず装具の理解必必要な基本的な生体 力学にふれ，なかんづく，三点支持の原理がいつも問題 となることを強調され，かつ日本的生活様式に適応した 装具の改良の必要性飞ふれ，下肢装具の基本的な構造， 適応飞ふれ, 最後飞, 片麻㽻, パラプレジア, 筋ジスト ロフィーの装具につき, 具体的な例を供覧しつつ言及さ れました。

装具飞関しましては, 更に医学教育の問題, 材料の問 題, 製作者の問題, 日本式装具の改良, あるいは生理的 な関節軸と接手の軸との関係など論ずれば限りがありま せんが今日のセミナーで，問題を提起したというのが実 情であり，今後の発展を祈ってやみません。

不慣れな司会のためと十分に論じ切れ せんでした が，上田先生に対して司会者として厚く祘礼を申しあげ るとともに，長時間とわたり熱心にご協力下さいました 皆さまに心から感謝いたします。 